STUDIA PRAWNO-EKONOMICZNE, T. CXIII, 2019

PL ISSN 0081-6841; e-ISSN 2450-8179 $\quad$ s. 259-280

https://doi.org/10.26485/SPE/2019/113/15

\title{
Radosław PIWOWARSKI*
}

iD https://orcid.org/0000-0001-7826-2527

\section{KSZTALTOWANIE MOTYWACJI NAUCZYCIELI AKADEMICKICH W POLSCE W KONTEKŚCIE WIELOZADANIOWEGO MODELU AGENCJI}

\begin{abstract}
Abstrakt
Przedmiot badań: Umiejętne kształtowanie motywacji w relacji pryncypał - agent jest podstawą efektywnego funkcjonowania zarówno podmiotów rynkowych, jak i organizacji. Problem wielozadaniowości agenta występujący na uczelniach może wiązać się z ukrytymi działaniami i pokusą nadużycia. Brak możliwości ciągłego monitorowania pracy nauczyciela akademickiego oraz trudności w mierzeniu jej efektywności sprzyjają powstawaniu tych zjawisk. Problem można rozwiązać poprzez odpowiednio zaprojektowany kontrakt.

Cel badawczy: Celem artykułu jest analiza rozwiązań odnoszących się do systemu finansowania szkolnictwa wyższego zawartych w Ustawie z dnia 20 lipca 2018 r. - Prawo o szkolnictwie wyższym i nauce w kontekście wielozadaniowego modelu agencji. Na tej podstawie przedstawia się propozycje rozwiązań motywacyjnych sprzyjających zwiększaniu efektywności pracy nauczyciela akademickiego w Polsce.

Metoda badawcza: W artykule analizuje się teoretyczny wielozadaniowy model agencji, który następnie uzupełniany jest o dane statystyczne oraz opis rozwiązań prawnych.

Wyniki: W części badawczej system motywacyjny powinien być oparty na punktach premiowych za każdą publikację powyżej danego limitu, natomiast powiązanie finansowania uczelni z liczbą studentów wskazywałoby na potrzebę wprowadzenia podobnego mechanizmu dla działalności dydaktycznej.
\end{abstract}

Słowa kluczowe: teoria agencji, model pryncypał - agent, system motywacyjny, uczelnie w Polsce.

Klasyfikacja JEL: D02, D86, D82

* Dr, Uniwersytet Łódzki, Wydział Ekonomiczno-Socjologiczny, Katedra Funkcjonowania Gospodarki; e-mail: radoslaw.piwowarski@uni.lodz.pl 


\section{Wstęp}

Umiejętne kształtowanie motywacji w relacji pryncypał - agent jest podstawą właściwego funkcjonowania zarówno podmiotów rynkowych, jak i organizacji (np. instytucji publicznych). Dotyczy to zwłaszcza wielozadaniowych, trudno mierzalnych aktywności agentów, których skuteczne monitorowanie jest utrudnione. Problem ukrytych działań i wynikająca z niego pokusa nadużycia mogą być wtedy rozwiązane poprzez odpowiednio zaprojektowany kontrakt ${ }^{1}$.

Optymalnemu kształtowaniu wielozadaniowych relacji oraz odpowiadającym im kontraktom poświęca się wiele miejsca w badaniach ekonomicznych. Rozwinięcie standardowego modelu agencji o wielozadaniowość i instrumenty kontroli znacznie zbliżyło go do rzeczywistości oraz stało się impulsem do pogłębionych analiz. W szczególności nowatorska praca Holströma i Milgro$\mathrm{ma}^{2}$ przyczyniła się do rozwoju literatury w tym obszarze. Poza nią, wśród najbardziej znanych prac dotyczących wielozadaniowych modeli agencji, można wymienić także: Bakera ${ }^{3}$, Felthama i Xie ${ }^{4}$, Gibbonsa ${ }^{5}$ czy Dewatripont, Jewitt i Tirole ${ }^{6}$.

Zaprojektowanie kontraktu mającego na celu optymalizację zależności pomiędzy pryncypałem i agentem wiąże się z potrzebą rozstrzygnięcia trzech podstawowych kwestii ${ }^{7}$. Pierwszą z nich jest ustalenie optymalnych bodźców dla agenta, drugą podział ryzyka pomiędzy pryncypałem i agentem, a trzecią wpływ czynników losowych na realizacje i wykonanie kontraktu ${ }^{8}$.

Bodźce oddziałujące na agenta kształtuje się przez formę kontraktu (np. liniowa zależność) oraz podstawę, do której odnosi się system motywacyjny. W przypadku firmy może być to jej wartość czy wytwarzany zysk. W rzeczy-

1 J. Wilkin, Instytucjonalne i kulturowe podstawy gospodarowania. Humanistyczna perspektywa ekonomii, Wydawnictwo Naukowe SCHOLAR, Warszawa 2016, s. 183-184.

2 B. Holmström, P. Milgrom, Multitask Principal-Agent Analyses: Incentive Contracts, Asset Ownership, and Job Design, Journal of Law, Economics, \& Organization 1991/7 (1).

3 G.P. Baker, Incentive Contracts and Performance Measurement, Journal of Political Economy 1992/100/3.

4 G. Feltham, J. Xie, Performance Measure Congruity and Diversity in Multi-Task Principal/ Agent Relations, The Accounting Review 1994/69 (3).

5 R. Gibbons, Incentives and Careers in Organizations, Journal of Economic Perspectives 1998/12 (4).

6 M. Dewatripont, I. Jewitt, J. Tirole, Multitask agency problems. Focus and task clustering, European Economic Review 2000/44, Issues 4-6.

7 Kwestie te rozstrzyga się niezależnie od stopnia skomplikowania modelu agencji.

8 J. Wilkin, op. cit., s. 184-185. 
wistości trudno implementować takie proste wskaźniki, przez co stosuje się bardziej skomplikowane podstawy lub arbitralnie przyjmuje różnego rodzaju mierniki ${ }^{9}$ Każda miara niesie jednak za sobą zakłócenie i ryzyko (ang. distortion and risk). Według Bakera znaczenie tego drugiego nie jest istotne. Znacznie większą uwagę powinno się skupiać na zakłóceniach. Rozumie się je jako formowanie motywacji (bodźców) agenta powodujące skupianie się przez niego na niewłaściwych lub mało znaczących dla pryncypała działaniach. Przykładowo, w modelu wielozadaniowym oznacza to skupianie się na jednym z zadań kosztem drugiego. Dzieje się tak, gdyż mierniki stosowane w kontrakcie nierówno rozkładają bodźce pomiędzy zadania, a ich dopasowanie do wyników działalności jest niewielkie lub istotne aktywności nie są po prostu mierzone ${ }^{10}$. Problemem, na który powinno się zwrócić szczególna uwagę, jest zatem dobre usytuowanie bodźców w powiązaniu z wynikami (celami pryncypała) ${ }^{11}$.

Drugą podstawową kwestią, którą należy rozstrzygnąć, jest podział ryzyka. Podejście do niego przez pryncypała i agenta będzie znajdywać swoje odzwierciedlenie w formie kontraktu. Agent posiadający awersję do ryzyka będzie wybierał bezpieczne dla siebie rozwiązania minimalizujące ryzyko, a co za tym idzie bardziej cenił pewny dochód niż jego wartość oczekiwaną. Przykładowo, agenci z awersją do ryzyka wolą unikać dużego znaczenia zmiennej części w uzyskiwanym dochodzie. Osoby pracujące w organizacjach (np. różnego rodzaju instytucje publiczne), gdzie wypłacane są najczęściej wyłącznie stałe wynagrodzenia, zdają się preferować tę formę zatrudnienia, nawet kosztem niższych poborów.

Oddziaływanie czynników losowych jest ostatnim z problemów, który należy rozstrzygnąć. Ich wpływ może mieć duże znaczenie, co wymaga uwzględnienia przy zawieraniu kontraktu. Czynniki sezonowe czy odpowiedni punkt w czasie mogą znacząco wpływać na mierniki lub wyniki przedsiębiorstwa (organizacji).

Problem wielozadaniowości agenta dość często pojawia się w systemie edukacji. Pracę nauczyciela (w tym również nauczyciela akademickiego) przywo-

9 Te ostatnie należy stosować bardzo rozważnie ze względu na możliwość pojawienia się zakłóceń skutkujących np. paradoksem efektywności. Więcej na temat paradoksu efektywności można znaleźć w: M.W. Meyer, V. Gupta, The performance paradox, Research in Organizational Behavior 1994/16 czy R. Piwowarski, Czy wskaźnik efektywności zatrudnieniowej ulega paradoksowi efektywności?, Acta Universitatis Lodziensis. Folia Oeconomica 2017/327 (1).

10 G. Baker, Distortion and Risk in Optimal Incentive Contracts, The Journal of Human Resources, Autumn, 2002/37/4, s. 729-730.

11 Należy w tym miejscu jednak zaznaczyć, że nie powinno się oczekiwać całkowitej zbieżności celów. Taka zbieżność może pojawiać się incydentalnie. 
łuje się nawet jako sztandarowy przykład, w którym wykonywanie poszczególnych zadań może wiązać się z ukrytymi działaniami i pokusą nadużycia ${ }^{12}$. Brak możliwości ciągłego monitorowania pracy nauczyciela oraz trudności w mierzeniu jej efektywności sprzyjają powstawaniu tych zjawisk. Poza tym, pojawia się tu również wymienność pomiędzy różnymi aktywnościami agenta. W szczególności, w przypadku nauczyciela akademickiego może wystąpić substytucja pomiędzy pracą dydaktyczną i badawczą. Payne i Roberts ${ }^{13}$, analizując wpływ dydaktycznego systemu motywacyjnego na publicznych uczelniach w USA, odnotowują ilościowy spadek grantów i publikacji naukowych, ale wyższą ich jakość. Silna korelacja występuje na nieflagowych uniwersytetach, a słaba lub jej brak na flagowych uczelniach. Brickley i Zimmerman ${ }^{14}$ dla Uniwersytetu Rochester Business School uzyskują jednoznacznie negatywny wpływ dydaktycznego systemu motywacyjnego na ilość badań, jednocześnie zauważając znaczący wzrost jakości dydaktyki mierzonej ewaluacją studentów. Substytucje pomiędzy wysiłkiem dydaktycznym i badawczym odnotowuje również de Philippis ${ }^{15}$, stwierdzając, że wprowadzenie na Uniwersytecie Bocconi systemu motywującego spowodowało pogorszenie się wskaźników dydaktycznych kosztem poprawy rezultatów badawczych. Ze względu na ograniczone rezultaty badawcze przyjęcie założenia o każdorazowym występowaniu substytucji pomiędzy działalnością dydaktyczną a badawczą na uczelniach wydaje się nieuprawnione. Pojawienie się systemu motywacyjnego naciskającego na któryś z elementów wydaje się jednak zwiększać prawdopodobieństwo jej pojawienia się. Wniosek ten wydaje się uprawniony w kontekście rozważań Marsha i Hattiego dotyczących powiązań pomiędzy działalnością dydaktyczną i naukową. Twierdzą oni, że korelacja pomiędzy nimi jest bliska zeru, a odnotowywane w badaniach dodatnie lub ujemne zależności mogą być wynikiem mocniejszego oddziaływania jednego z szeregu czynników wiążących dydaktykę i naukę. Wśród czynników wymieniają: zdolności do działalności dydaktycznej i naukowej, satysfakcję z pracy dydaktycznej i naukowej, cele osobiste, ograniczenia w pracy dydak-

12 P. Bolton, M. Dewatripont, Contract Theory, The MIT Press, London 2005, s. 218; M. de Philippis, Multitask agents and incentives: the case of teaching and research for university professors, Temi di Discussione (Working Papers) 2015/1042, s. 5.

13 A. Payne, J. Roberts, Government oversight of public universities: Are centralized performance schemes related to increased quantity or quality?, The Review of Economics and Statistics 2010/92 (1).

14 J.A. Brickley, J.L. Zimmerman, Changing incentives in a multitask environment: evidence from a top-tier business school, Journal of Corporate Finance 2001/7 (4).

15 M. de Philippis, op. cit. 
tycznej i naukowej czy „zewnętrzne nagrody” za działalność dydaktyczną i naukową $^{16}$. Wprowadzenie systemu motywacyjnego skupiającego się na danym rodzaju aktywności będzie zatem sprzyjać substytucji, zwłaszcza przy ograniczeniu czasowym. Poza tym, osoby czy podmioty po prostu reagują na bodźce, choć ich zachowania mogą się od siebie w jakimś stopniu różnić. Fryer i Holden przeprowadzili eksperyment w szkołach publicznych w Houston, w którym potwierdzili wnioski wynikające z teoretycznego modelu agencji. Wprowadzenie bodźca ${ }^{17}$ wpłynęło na zachowania, uczniów, nauczycieli i rodziców. Autorzy badania odnotowali poprawę zachowań w obszarach podlegających systemowi motywacji. Zaznaczają jednak, że po zaprzestaniu stosowania finansowej motywacji jej pozytywny wpływ pozostał wśród lepszych uczniów, a gorsi obniżyli swoje wyniki. Tłumaczą to faktem poznania swoich możliwości i utrzymaniem wewnętrznej motywacji w grupie lepszych uczniów ${ }^{18}$.

Celem artykułu jest analiza rozwiązań odnoszących się do systemu finansowania szkolnictwa wyższego zawartych w Ustawie z dnia 20 lipca 2018 r. - Prawo o szkolnictwie wyższym i nauce ${ }^{19}$ (tzw. Konstytucja dla Nauki) w kontekście teoretycznego modelu agencji. Przedstawiony model agencji opisuje zachowanie nauczyciela akademickiego (agenta), który dzieli swoją aktywność pomiędzy działalność badawczą i dydaktyczną. Uczelnia ${ }^{20}$ (pryncypał) maksymalizuje natomiast funkcję zysku, która zależy od tych dwóch wysiłków agenta. $\mathrm{Na}$ tej podstawie proponowany jest hipotetyczny system motywacyjny.

Struktura opracowania jest następująca. W podpunkcie drugim przedstawiany jest teoretyczny model. Podpunkt trzeci opisuje najważniejsze rozwiązania dotyczące „motywacji uczelni” i nauczyciela akademickiego. Kolejny podpunkt stanowi próbę sformułowania optymalnej strategii w postaci systemu motywacyjnego. Ostatni rozdział zawiera podsumowanie prowadzonej analizy.

16 H.W. Marsh, J. Hattie, The Relation between Research Productivity and Teaching Effectiveness: Complementary, Antagonistic, or Independent Constructs?, The Journal of Higher Education, Sep.-Oct., 2002/73/5, s. 608-611.

17 W tym przypadku był to pieniężny system motywacyjny.

18 R.G. Jr. Fryer, R.T. Holden, Multitasking, dynamic complementarities, and incentives: A cautionary tale. Technical report, Cambridge, Massachusetts: Harvard University 2013, s. $31-32$.

19 Dz.U. z 2018 r., poz. 1668.

20 Pod pojęciem uczelni jako pryncypała rozumie się zwierzchnika nauczyciela akademickiego, który jednocześnie „nadzoruje” jego pracę oraz jest odpowiedzialny za tworzenie systemu motywacyjnego. W większości przypadków modelowego pryncypała będzie utożsamiać się z funkcją dziekana. 
Artykuł ma przede wszystkim teoretyczny charakter, który następnie uzupełniany jest o dane statystyczne oraz opis rozwiązań prawnych. W przyszłości warto poszerzyć prowadzone badanie o empiryczną weryfikację prezentowanego modelu. W tym celu należy pozyskać dane z jednej z polskich uczelni, która stosuje system motywacyjny. Takie próby warto podjąć.

\section{Model}

Przedstawiony poniżej model stanowi modyfikację modelu Holströma i Milgroma $^{21}$ oraz jest uproszczoną wersją modelu prezentowanego przez Bakera ${ }^{22}$. Uproszczenie polega na ograniczeniu się wyłącznie do analizy dwóch aktywności agenta będącego nauczycielem akademickim. Są nimi działalność badawcza oraz dydaktyczna.

Poza tym poniższy model poszerza analizę problemu substytucji wysiłków oraz niedoskonałości miar stosowanych w systemach motywacyjnych, w stosunku do zbliżonych modeli prezentowanych przez de Philippis ${ }^{23}$ oraz Fryera i Holdena ${ }^{24}$. W ich pracach nacisk położony jest przede wszystkim na zachowanie agenta oraz jego motywacje, nie rozwija się natomiast problemu zbieżności funkcji celów podmiotów. Niedopasowanie miary systemu motywacyjnego do funkcji produkcji (funkcja celu pryncypała) jest ważnym problemem, który może być rozważany w modelu. Przyjęcie różnych współczynników w funkcji produkcji ${ }^{25}$ oraz mierze (indeksie) systemu motywacyjnego pozwala na określenie możliwości pojawienia się zakłóceń. Wydaje się to uzasadnione choćby w kontekście odmienności algorytmu stosowanego przez Ministerstwo Nauki i Szkolnictwa Wyższego do obliczania dotacji dla uczelni, a wewnętrznymi rozwiązaniami każdego z podmiotów używanych w systemach motywacyjnych ${ }^{26}$.

Przyjmuje się, że nauczyciel akademicki angażuje się w pracy w dwa rodzaje aktywności: badawczą $\left(e_{r}-\right.$ wysiłek badawczy) i dydaktyczną $\left(e_{t}-\right.$ wysi-

\footnotetext{
${ }^{21}$ B. Holmström, P. Milgrom, op. cit.

G. Baker, Distortion and Risk...

M. de Philippis, op. cit.

R.G. Jr. Fryer, R.T. Holden, op. cit.

25 Używane pojęcie funkcja produkcji rozumiane jest szeroko. Będzie to wszystko to, co agent wnosi do organizacji.

26 Można zakładać, że wewnętrzne systemy motywacyjne będą dopasowywać się do rozwiązań ministerialnych, co nie oznacza ich całkowitego skopiowania. Choćby złożoność algorytmu dotacji dla uczelni nie pozwala na jego powielenie w systemie motywacyjnym.
} 
łek dydaktyczny). W wyniku podejmowanych aktywności pojawia się produkcja uczelni, którą opisuje funkcja (technologia produkcji uczelni):

$$
y=f_{r} e_{r}+f_{t} e_{t}+\varepsilon_{y}, \text { zakładając } \varepsilon_{y} \sim N\left(0, \sigma^{2}\right) .
$$

Miara (indeks) systemu motywacyjnego przyjmuje postać:

$$
\begin{gathered}
p=g_{r} e_{r}+g_{t} e_{t}+\varepsilon_{p}, \text { zakładając } \varepsilon_{p} \sim N\left(0, \sigma^{2}\right) . \\
\operatorname{Cov}\left(\varepsilon_{y}, \varepsilon_{p}\right)=\rho \sigma_{y} \sigma_{p}
\end{gathered}
$$

Gdzie $f_{r}, f_{t}, g_{r}$ i $g_{t}$ są krańcowymi produktami wpływającymi odpowiednio na: wielkość produkcji oraz wartość miary systemu motywacyjnego ${ }^{27}$. Ten sam wysiłek badawczy czy dydaktyczny może krańcowo inaczej oddziaływać na przychody uczelni oraz na premię otrzymywaną przez nauczyciela akademickiego. Przykładowo, uczelnia potrzebuje do pozytywnej ewaluacji najwyżej punktowanych czasopism z tzw. listy A. W systemie motywacyjnym uwzględnia jednak również mniej prestiżowe czasopisma oraz monografie. Nauczyciel akademicki będzie kierował się uzyskaniem najwyższych wartości „p”, patrząc na współczynniki z systemu motywacyjnego, a nie te z funkcji produkcji. Interesuje go zdobycie największej liczby punktów w systemie motywacyjnym, nie zważając na to, jakie będzie to miało przełożenie na ewaluacje danej jednostki. Krańcowe produkty będą tu zatem różne. Poza tym wielkości krańcowych produktów są uzależnione od zdolności czy umiejętności agenta do pracy w danych obszarach.

Przyjmuje się, że kształt kontraktu pomiędzy pryncypałem i agentem ma postać liniową:

$$
W=s+b p,
$$

gdzie: $s$ to stała część wynagrodzenia (niezależna od wysiłku), a $b p$ zmienna (uzależniona od miary systemu motywacyjnego i wielkości współczynnika $b$ ).

Funkcja zysku uczelni będzie różnicą pomiędzy wielkością produkcji a wynagrodzeniem wynikającym z kontraktu:

$$
\pi=y-w .
$$

Nauczyciel akademicki posiada awersję do ryzyka opisaną funkcją użyteczności typu CARA (CARA - ang. constant absolute risk aversion):

27 Zakłada się, że przyjmują wartości dodatnie różne od zera. 


$$
U\left(w, e_{r}, e_{t}\right)=-e^{-\eta\left[w-c\left(e_{r}, e_{t}\right)\right]},
$$

oraz funkcję kosztów:

$$
c\left(e_{r}, e_{t}\right)=\frac{1}{2} e_{r}^{2}+\frac{1}{2} e_{t}^{2}+\delta e_{r} e_{t},
$$

gdzie $\delta$ pokazuje stopień substytucyjności wysiłków $(-1<\delta<1)$. Jeśli $\delta=0$ wysiłki są całkowicie niezależne od siebie. Dla wartości ujemnych występuje komplementarność kosztów, tj. krańcowy koszt wysiłku dydaktycznego zmniejsza się wraz ze wzrostem wysiłku badawczego i odwrotnie $\left(\frac{\partial M C_{e_{r}}}{\partial e_{t}}<0 ; \frac{\partial M C_{e_{t}}}{\partial e_{r}}<0\right)$. Wysiłki są zatem komplementarne wobec siebie. Dla wartości dodatnich wysiłki będą substytucyjne.

Nauczyciel akademicki maksymalizuje ekwiwalentną funkcję użyteczności w warunkach pewności (ang. certainty equivalent compensation) postaci ${ }^{28}$ :

$$
{ }_{e_{r}, e_{t}}^{\max } C E=s+b\left(g_{r} e_{r}+g_{t} e_{t}\right)-\frac{1}{2} e_{r}^{2}-\frac{1}{2} e_{t}^{2}-\delta e_{r} e_{t}-\frac{\eta}{2} b^{2} \sigma_{p}^{2}
$$

Maksymalizując funkcję (7), otrzymuje się optymalne wielkości wysiłku badawczego i dydaktycznego:

$$
\begin{gathered}
e_{r}^{*}=\frac{b g_{r}-\delta b g_{t}}{1-\delta^{2}} \\
e_{t}^{*}=\frac{b g_{t}-\delta b g_{r}}{1-\delta^{2}}
\end{gathered}
$$

Obliczając pochodne cząstkowe równań (8) i (9) względem $g_{r}, g_{t}$ i $b$, otrzymuje się:

$$
\begin{gathered}
\frac{\partial e_{r}^{*}}{\partial g_{r}}=\frac{b}{1-\delta^{2}}>0 \\
\frac{\partial e_{r}^{*}}{\partial g_{t}}=\frac{-b \delta}{1-\delta^{2}} ;\left\{\begin{array}{c}
>0 \text { dla } \delta<0 \text { (komplementarne) } \\
<0 \text { dla } \delta>0 \text { (substytuty) }
\end{array}\right\}
\end{gathered}
$$

${ }^{28}$ Wyprowadzenie znajduje się w Załączniku 1. 


$$
\frac{\partial e_{r}^{*}}{\partial b}=\frac{g_{t}-\delta g_{r}}{1-\delta^{2}} ;\left\{\begin{array}{l}
>0 \text { dla } \delta<0 \text { (komplementarne) } \\
<0 \text { dla } \delta>0 \text { (substytuty) }
\end{array}\right.
$$

Z równania (10) wynika, że wraz ze wzrostem krańcowego produktu w odniesieniu do działalności badawczej będzie rósł wysiłek badawczy. Wyższy krańcowy produkt z działalności dydaktycznej będzie pozytywnie oddziaływał na wysiłek badawczy wyłącznie w przypadku, gdy obie aktywności będą w stosunku do siebie komplementarne. Komplementarność aktywności będzie również sprzyjać zwiększaniu wysiłku badawczego w przypadku zwiększenia współczynnika stosowanego w systemie motywacyjnym.

$$
\begin{gathered}
\frac{\partial e_{t}^{*}}{\partial g_{t}}=\frac{b}{1-\delta^{2}}>0 \\
\frac{\partial e_{t}^{*}}{\partial g_{r}}=\frac{-b \delta}{1-\delta^{2}} ;\left\{\begin{array}{l}
>0 \text { dla } \delta<0 \text { (komplementarne) } \\
<0 \text { dla } \delta>0 \text { (substytuty) }
\end{array}\right. \\
\frac{\partial e_{t}^{*}}{\partial b}=\frac{g_{t}-\delta g_{r}}{1-\delta^{2}} ;\left\{\begin{array}{l}
>0 \text { dla } \delta<0 \text { (komplementarne) } \\
<0 \text { dla } \delta>0 \text { (substytuty) }
\end{array}\right.
\end{gathered}
$$

Analogiczne wnioski do tych zaprezentowanych dla aktywności badawczej można sformułować dla działalności dydaktycznej (por. równania (13)-(15) z (10)-(12)).

Niezależnie od rodzaju prowadzonej aktywności problemem, przed którym staje pryncypał, jest wyznaczenie optymalnej wielkości współczynnika $b$. Aby wyprowadzić optymalne $b$, należy określić oczekiwany zysk uczelni oraz wynagrodzenie agenta. Wyniosą one:

$$
\begin{gathered}
E(\pi)=f_{r} e_{r}+f_{t} e_{t}-s-b g_{r} e_{r}-b g_{t} e_{t} \\
E(w)=s+b\left(g_{r} e_{r}+g_{t} e_{t}\right)-\frac{1}{2} e_{r}^{2}-\frac{1}{2} e_{t}^{2}-\delta e_{r} e_{t}-\frac{\eta}{2} b^{2} \sigma_{p}^{2}
\end{gathered}
$$

Sumując (16) i (17), otrzymuje się:

$$
E(\pi+w)=f_{r} e_{r}+f_{t} e_{t}-\frac{1}{2} e_{r}^{2}-\frac{1}{2} e_{t}^{2}-\delta e_{r} e_{t}-\frac{\eta}{2} b^{2} \sigma_{p}^{2}
$$


Uwzględniając obliczone wcześniej optymalne wielkości $e_{r}^{*}$ i $e_{r}^{*}$, otrzymuje się problem maksymalizacyjny, na jaki napotka pryncypał przy wyznaczeniu optymalnego $b^{29}$ :

$$
\begin{aligned}
& { }_{b}^{\max } f_{r}\left(\frac{b g_{r}-\delta b g_{t}}{1-\delta^{2}}\right)+f_{t}\left(\frac{b g_{t}-\delta b g_{r}}{1-\delta^{2}}\right)-\frac{1}{2}\left(\frac{b g_{r}-\delta b g_{t}}{1-\delta^{2}}\right)^{2}-\frac{1}{2}\left(\frac{b g_{t}-\delta b g_{r}}{1-\delta^{2}}\right)^{2}- \\
& \delta\left(\frac{b g_{r}-\delta b g_{t}}{1-\delta^{2}}\right)\left(\frac{b g_{t}-\delta b g_{r}}{1-\delta^{2}}\right)-\frac{\eta}{2} b^{2} \sigma_{p}^{2}
\end{aligned}
$$

Jego wartość wyniesie:

$$
b^{*}=\frac{f_{r} g_{r}+f_{t} g_{t}-\delta\left(f_{t} g_{r}-f_{r} g_{t}\right)}{g_{r}{ }^{2}+g_{t}{ }^{2}-2 \delta^{2}\left(g_{t}{ }^{2}+g_{r}{ }^{2}\right)-2 \delta g_{t} g_{r}\left(1-\delta-\delta^{2}\right)+\left(\eta \sigma_{p}^{2}\right)\left(1-\delta^{2}\right)}
$$

Przyjmując, że $\delta=0$ współczynnik $b$ ma wartość:

$$
b^{*}=\frac{f_{r} g_{r}+f_{t} g_{t}}{g_{r}^{2}+g_{t}^{2}+\eta \sigma_{p}^{2}}
$$

Korzystając ze wzoru na iloczyn skalarny oraz na długość wektora, można go zapisać jako:

$$
b^{*}=\frac{|\vec{f}||\vec{g}| \cos \theta}{|\vec{g}|^{2}+\eta \sigma_{p}^{2}}
$$

Równanie (22) pokazuje, na co należy zwrócić uwagę przy wyznaczaniu optymalnego poziomu zmiennej części kontraktu. Dla $\cos \theta=0$ wartość współczynnika $b$ powinna wynosić zero, a dla $\cos \theta=1$ powinna być ona najwyższa. Oznacza to, że wielkość współczynnika $b$ będzie zależeć od wzajemnej relacji wektorów $|\vec{f}| i|\vec{g}|$ (por. rysunek 1). W przypadku gdy wektory są ortogonalne ( $\cos \theta=0$ ), wysiłki agenta determinowane przez system motywacyjny nie będą się w żaden sposób przekładać na zyski pryncypała. W przypadku pokrywania się wektorów $(\cos \theta=1)$ wysiłki agenta w pełni przełożą się na zyski pryncypała ${ }^{30}$.

29 Wyprowadzenie rozwiązania problemu optymalizacyjnego znajduje się w Załączniku 2.

30 W rzeczywistości taka sytuacja wydaje się być mało prawdopodobna, gdyż trudno oczekiwać, że stosowane w systemach motywacyjnych wskaźniki będą w pełni odzwierciedlać algorytm stosowany przy obliczaniu dotacji. 
RYSUNEK 1: Przykładowe położenie wektorów

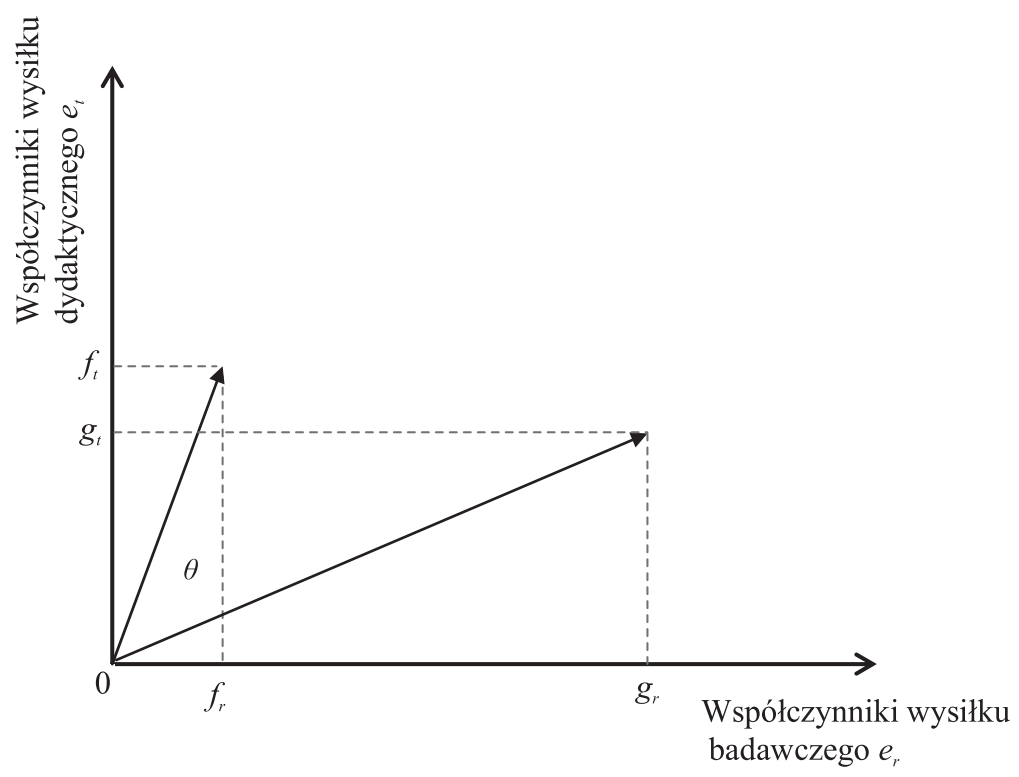

Oprócz położenia wektorów względem siebie istotna jest również ich długość. Wielkość produktów krańcowych będzie determinować skalę przełożenia wysiłku agenta na osiągane przez pryncypała zyski.

\section{3. „Motywacje uczelni” i motywacje nauczyciela akademickiego}

Większość środków finansowych uczelni państwowych pochodzi z różnego rodzaju dotacji. Wśród przychodów z działalności operacyjnej dominują środki dydaktyczne (por. tabela 1). Drugą pozycję zajmują środki z działalności badawczej. Uczelnie uzyskują również przychody z innych rodzajów działalności, jednak nie mają one dużego znaczenia.

Dotychczasowy model finansowania uczelni ulega jednak zmianie. W okresie przejściowym trudno oczekiwać znaczącej zmiany struktury przychodów, jednak w dłuższej perspektywie znaczenie działalności dydaktycznej może ulec zmniejszeniu. 
TABELA 1: Struktura przychodów z działalności operacyjnej w szkołach wyższych wedtug rodzaju działalności w 2017 r. w\%

\begin{tabular}{|l|c|c|c|c|c|}
\hline Wyszczególnienie & $\begin{array}{c}\text { Przychody } \\
\text { z działalności } \\
\text { dydaktycznej }\end{array}$ & $\begin{array}{c}\text { Przychody } \\
\text { z działalności } \\
\text { badawczej }\end{array}$ & $\begin{array}{c}\text { Przychody } \\
\text { z wydzielonej } \\
\text { działalności } \\
\text { gospodarczej }\end{array}$ & $\begin{array}{c}\text { Przychody } \\
\text { ze sprzedaży } \\
\text { towarów } \\
\text { i materiałów }\end{array}$ & $\begin{array}{c}\text { Pozostałe } \\
\text { przychody } \\
\text { operacyjne }\end{array}$ \\
\hline Ogółem & 79,6 & 12,7 & 0,6 & 0,1 & 6,6 \\
\hline $\begin{array}{l}\text { Wyższe szkoły } \\
\text { publiczne }\end{array}$ & 78,6 & 13,7 & 0,6 & 0,1 & 6,6 \\
\hline Uniwersytety & 76,5 & 16,4 & 0,0 & 0,0 & 6,4 \\
\hline $\begin{array}{l}\text { Wyższe szkoły } \\
\text { ekonomiczne }\end{array}$ & 93,7 & 4,5 & 0,0 & 0,0 & 1,5 \\
\hline
\end{tabular}

Źr ód ło: Szkoły wyższe i ich finanse w 2017 r., GUS, s. 253.

W świetle projektowanego rozporządzenia ${ }^{31}$ do Ustawy z dnia 20 lipca 2018 r. - Prawo o szkolnictwie wyższym i nauce, subwencja będzie zależeć zarówno od kategorii naukowej jednostki (przyjęto podział na kategorie od C do $\mathrm{A}+$ ), jak i grupy, w której się znajdzie się dana jednostka. W rozporządzeniu uczelnie dzieli się na dwie grupy ${ }^{32}$. Pierwsza grupa to publiczne uczelnie akademickie, z którymi minister zawarł umowy w ramach rozstrzygnięcia konkursu programu „Inicjatywa doskonałości - uczelnia badawcza” (uczelnie badaw$\left.\mathrm{cze}^{33}\right)$. Drugą grupę stanowią pozostałe publiczne uczelnie akademickie, nadzorowane przez ministra (uczelnie dydaktyczne ${ }^{34}$ ).

31 Projekt z dnia 14 września 2018 r., W sprawie sposobu podziału środków finansowych na utrzymanie i rozwój potencjału dydaktycznego oraz potencjału badawczego znajdujących się w dyspozycji ministra właściwego do spraw szkolnictwa wyższego i nauki oraz na zadania związane z utrzymaniem powietrznych statków szkolnych i specjalistycznych ośrodków szkoleniowych kadr powietrznych, https://legislacja.rcl.gov.pl/projekt/12322309/kata$\log / 12604666 \# 12604666$; stan na 25.07.2019 r. W artykule pomija się grupę uczelni o profilu zawodowym. Dla nich stosuje się odrębny algorytm. Posiadanie przez uczelnie kategorii C lub B w jakiejkolwiek z dyscyplin eliminuje ją z możliwości ubiegania się o miano uczelni badawczej.

34 Nazywa się je tak na potrzeby artykułu. W świetle przepisów są to uczelnie badawczo-dydaktyczne. 
Proponowany algorytm subwencji obliczany jest według wzoru:

$$
D u_{i}=F \times\left(\frac{D p_{i}}{\sum_{i=1}^{n} D p_{i}} \times C+(1-C) \times\left(W_{s} \times S_{i} \times W_{k} \times K_{i}+W_{u} \times U_{i}+W_{b} \times B_{i}+W_{d} \times D_{i}+W_{n} \times N_{i}+W_{p} \times P_{i}\right)\right)
$$

gdzie:

$D u_{i}$ - wysokość subwencji na utrzymanie i rozwój potencjału dydaktycznego oraz potencjału badawczego, z części zasadniczej dla i-tej publicznej uczelni akademickiej w danym roku,

$F$ - kwota przyjęta do obliczenia części zasadniczej dla grupy publicznych uczelni akademickich,

$D p_{i}$ - oznacza wysokość subwencji dla i-tej publicznej uczelni akademickiej w poprzednim roku, w warunkach porównywalnych,

$C$ - stała przeniesienia,

$W_{s}$ - waga składnika studenckiego,

$S_{i}$ - składnik studencki i-tej publicznej uczelni akademickiej,

$W_{k}$ - waga składnika kadrowego,

$K_{i}$ - składnik kadrowy i-tej publicznej uczelni akademickiej,

$W_{u}$ - waga składnika umiędzynarodowienia,

$U_{i}^{u}$ - składnik umiędzynarodowienia i-tej publicznej uczelni akademickiej,

$W_{b}$ - waga składnika badawczego,

$B_{i}$ - składnik badawczy i-tej publicznej uczelni akademickiej,

$W_{d}$ - waga składnika doktoranckiego,

$D_{i}$ - składnik doktorancki i-tej publicznej uczelni akademickiej,

$W_{n}$ - waga składnika badawczo-rozwojowego,

$N_{i}^{n}$ - składnik badawczo-rozwojowy i-tej publicznej uczelni akademickiej,

$W_{p}$ - waga składnika projektowego,

$P_{i}$ - składnik projektowy i-tej publicznej uczelni akademickiej,

$n-$ liczba publicznych uczelni akademickich w grupie publicznych uczelni akademickich.

W zależności od tego, w której grupie znajdzie się uczelnia, przyjmuje się różne wagi dla poszczególnych składników algorytmu (por. tabela 2). 
TABELA 2: Docelowe i tymczasowe wagi algorytmu podziału subwencji dla grup uczelni ${ }^{35}$

\begin{tabular}{|c|c|c|c|c|}
\hline $\begin{array}{c}\text { Składnik } \\
\text { algorytmu/ } \\
\text { typ uczelni }\end{array}$ & \multicolumn{2}{|c|}{ „Uczelnia badawcza” } & \multicolumn{2}{c|}{ Pozostałe uczelnie } \\
\hline$C$ & 0,25 & $0,45^{*}$ & 0,25 & $0,45^{*}$ \\
\hline$W_{s}$ & 0,20 & $0,28^{*}$ & 0,30 & $0,34^{*}$ \\
\hline$W_{k}$ & 0,20 & $0,25^{*}$ & 0,25 & $0,25^{*}$ \\
\hline$W_{u}$ & 0,05 & $0,05^{*}$ & 0,05 & $0,05^{*}$ \\
\hline$W_{b}$ & 0,30 & $0,25^{*}$ & 0,25 & $0,25^{*}$ \\
\hline$W_{d}$ & 0,10 & $0,02^{*}$ & 0,05 & $0,01^{*}$ \\
\hline$W_{n}$ & 0,10 & $0,10^{*}$ & 0,10 & $0,10^{*}$ \\
\hline$W_{p}$ & 0,05 & $0,05^{*}$ & 0,00 & $0,00^{*}$ \\
\hline $\begin{array}{c}\text { Referencyjna } \\
\text { liczba studentów } \\
\text { na nauczyciela } \\
\text { akademickiego }\end{array}$ & 10 & $12,5^{*}$ & 13 & $13^{*}$ \\
\hline
\end{tabular}

Źr ód ło: projekt rozporządzenia, opracowanie własne; * - wagi dla roku 2020.

Rozbieżności $\mathrm{w}$ prezentowanych docelowych wagach są niewielkie. W przypadku uczeni badawczych położono większy nacisk na: badania (waga 0,3 zamiast 0,25 ), kształcenie doktorantów (waga 0,1 zamiast 0,05 ) oraz projekty (waga 0,05 zamiast 0,0 ). Uczelnie badawcze mają posiadać mniejszą referencyjną liczbę studentów na nauczyciela akademickiego. W przypadku uczelni dydaktycznych większe znacznie nadano: kształceniu studentów (waga 0,3 zamiast 0,2 ) oraz ,jakości” kadry (waga 0,25 zamiast 0,2 ). Na wysokość subwencji dla uczelni dydaktycznych nie mają wpływu realizowane projekty.

Na podstawie przedstawionych informacji trudno ocenić, jak różnice w wagach będą wpływać na finalną kwotę subwencji. Wydaje się, że zasadnicze różnice będą wynikiem przyjęcia różnych kwot $F$ w poszczególnych grupach uczelni. W prezentowanych przez Ministerstwo Nauki i Szkolnictwa Wyższego

35 Prezentowane $\mathrm{w}$ tabeli wagi są wagami docelowymi. Zostały sporządzone na podstawie Załącznika 1 do projektowanego rozporządzenia. W rozporządzeniu przedstawiane są również wagi dla okresu przejściowego, tj. dla lat 2019-2023. W tabeli 2. pokazano jako przykład wagi dla lat 2019 i 2020 w poszczególnych grupach. 
materiałach, w grupie uczelni badawczych ma się znaleźć nie więcej niż 10 jednostek $^{36}$. Będą to zatem najlepsze uczelnie w Polsce. Można przypuszczać, że kwota $F$ dla tej grupy uczelni będzie wyższa, co znacząco wpłynie na wysokość subwencji. Różnice w wysokości subwencji pomiędzy poszczególnymi uczelniami w danej grupie będą uzależnione od poszczególnych wskaźników algorytmu. Biorąc pod uwagę wagi, największą rolę odgrywają obszary: dydaktyczny, kadrowy i badawczy. Wielkość dwóch ostatnich uzależniona jest od awansu pracowników oraz od posiadanej kategorii naukowej w dyscyplinach. Im więcej pracowników będących profesorami oraz im wyższa kategoria, tym wyższa kwota subwencji. Wydaje się, że uczelnie powinny kłaść nacisk na awans naukowy własnej kadry oraz na posiadanie jak najwyższej kategorii naukowej w każdej z dyscyplin. Przyjęcie takiej strategii będzie zwiększać prawdopodobieństwo znalezienia się $w$ grupie jednostek badawczych lub otrzymywania wyższej kwoty subwencji w ramach grupy uczelni dydaktycznych. Z punktu widzenia pryncypała (uczelni) formowanie odpowiednich bodźców dla działalności badawczej będzie korzystne. Działalność dydaktyczna wydaje się mieć mniejsze znacznie. W kontekście przedstawionej w tabeli 1 struktury przychodów uczelni należy spodziewać się zmian systemowych w tym obszarze.

Położenie dużego nacisku na działalność badawczą może negatywnie wpływać na działalność dydaktyczną wtedy, gdy wysiłki dydaktyczny i badawczy będą substytucyjne wobec siebie ${ }^{37}$. W takim przypadku motywacje nauczycieli akademickich, aby przykładać dużą wagę do prowadzonej dydaktyki, mogą ulec zmniejszeniu.

Odejście od systemu dotacji uzależnionej od liczby studentów wydaje się wpływać na sposób pracy dydaktycznej na uczelni. Zmniejszenie ogólnej liczby miejsc na studiach powoduje, że znajdą się na nich najlepsi uczniowie. Ich oczekiwania odnośnie do jakości kształcenia mogą być wyższe. W tym kontekście zmniejszenie motywacji dydaktycznej nauczycieli akademickich będzie niekorzystne dla uczelni. Prowadzenie niskiej jakości dydaktyki w długim okresie odbije się na liczbie studentów na uczelni, a co za tym idzie niższej subwencji (liczba studentów spadnie poniżej wartości referencyjnej).

$\mathrm{Z}$ jednej strony formalne zniesienie wymogu habilitacji $\mathrm{w}$ Ustawie $\mathrm{z}$ dnia 20 lipca 2018 r. - Prawo o szkolnictwie wyższym i nauce likwiduje presję wytężonej pracy badawczej po doktoracie, $\mathrm{z}$ drugiej strony stworzony system finansowania uczelni tworzy presję na prowadzenie jak najlepszych badań.

\footnotetext{
https://nkn.gov.pl/wp-content/uploads/2017/09/uczelnie.pptx; stan na 18.07.2019 r.

37 Teza ta znajduje potwierdzenie w przedstawiony wcześniej modelu.
} 
Z punktu widzenia agenta (nauczyciela akademickiego) awans naukowy nadal pozostaje istotny, choć stopień istotności będzie uzależniony od typu uczelni. Najlepsze uczelnie badawcze będą otrzymywały najwyższe subwencje. Znacznie większa autonomia uczelni odnosząca się do wydatkowania subwencji może spowodować znaczne różnicowanie zarobków. W efekcie najlepsze uczelnie będą przyciągać najlepszych naukowców. W tych przypadkach awans naukowy będzie czymś naturalnym i pożądanym. Należy w tym miejscu zaznaczyć, że uzyskanie stopnia czy tytułu profesora nie będzie gwarantować stabilności zatrudnienia, gdyż ocenie podlega bieżąca działalność nauczyciela akademickiego niezależnie od zajmowanego stanowiska. Dostosowanie się do nowych wymagań odnoszących się do wysiłku badawczego może odbywać się kosztem wysiłku dydaktycznego, co stanowiłoby zagrożenie dla dobrej jakości dydaktyki na uczelniach badawczych. W przypadku uczelni dydaktycznych motywacje i możliwości szybkiego awansu naukowego mogą być mniejsze. Mimo to stworzenie odpowiedniego systemu motywacyjnego (premiowego) może skutecznie przyciągać i zatrzymywać dobrych pracowników z ambicjami badawczymi ${ }^{38}$. Istotnym wydaje się być różnica w wielkości zarobków w obydwu typach uczelni, którą dziś trudno jest określić.

\section{System motywacyjny}

Stworzenie dobrego systemu motywacyjnego może być kluczowe dla pozycji uczelni. Zwiększona autonomia odnosząca się do sposobu wydatkowania subwencji wydaje się sprzyjać powstawaniu systemów premiowych. Kluczowym dla systemu motywacyjnego zapisem w rozporządzeniu ${ }^{39}$ do nowej ustawy o szkolnictwie wyższym jest przedstawienie do oceny parametrycznej jednostki liczby publikacji $3 \mathrm{~N}$, którą tworzą maksymalnie 4 najlepsze publikacje każdego pracownika pracującego $\mathrm{w}$ dyscyplinie. Zmienia to dotychczasowy system, w którym kilka osób mogło „pociągnąć” ocenę jednostki. Aktualnie o jej jakości będzie decydować ogół zatrudnionych pracowników. Uczelni powinno zależeć, aby każdy z pracowników publikował w jak najwyżej punktowanych czasopi-

$38 \mathrm{Z}$ pewnością czynnik finansowy nie jest jedynym przy podejmowaniu decyzji odnośnie do zatrudnienia. Nie bez znaczenia pozostają również inne czynniki, jak np. prestiż, motywacje wewnętrzne itd. $Z$ punktu widzenia celu pracy oraz na tym poziomie ogólności rozważań unika się ich rozstrzygania.

39 Projekt rozporządzenia z dnia 22 lutego 2018, w sprawie ewaluacji jakości działalności naukowej. 
smach. Poziom naukowy każdej z jednostek może być wtedy „wyznaczany” poprzez ustalenie minimalnych wymogów dotyczących punktów.

Z modelowej analizy wynika, że wpływ na wielkość zysku uczelni oraz miarę systemu motywacyjnego mają produkty krańcowe $\left(f_{r}, f_{t}, g_{r}\right.$ i $\left.g_{t}\right)$. Są one uzależnione od zdolności czy umiejętności agenta do pracy w danych obszarach. Z tego punktu widzenia system powinien w jak największym stopniu uwzględniać indywidualne przypadki. Wśród pracowników uczelni znajdą się tak osoby $\mathrm{z}$ większymi zdolnościami do prowadzenia badań, jak i osoby bardziej oddane działalności dydaktycznej. Zarówno jednych, jak i drugich powinno się motywować do choćby pojedynczych sukcesów w obszarze niebędącym ich specjalnością. Jeśli „typowemu dydaktykowi” uda się napisać bardzo dobry artykuł naukowy, powinien być za to nagrodzony. Każdorazowo jest to korzyść dla uczelni, gdyż pozwala podnieść średnią punktację publikacji jednostki (dyscypliny). Takie podejście wydaje się być również wskazane w kontekście nowego systemu parametryzacji, w którym uwzględnia się publikację każdego pracownika.

Pasującym tu rozwiązaniem jest system motywacyjny, który nagradza każdy opublikowany wysoko punktowany artykuł. Przykładowo, uczelnia ustala minimalną liczbę punktów dla artykułów zaliczanych do premii na poziomie $99 \mathrm{pkt}^{40}$. Pracownik, aby ją otrzymać, musi publikować w czasopismach powyżej tej wielkości, np. 100 pkt i więcej. Taki system wydaje się zachęcać do publikacji w jak najlepszych czasopismach. Skupienie bodźców motywacyjnych nawet na pojedynczych publikacjach jest korzystne przynajmniej z dwóch powodów. Po pierwsze, likwiduje się problem niekorzystnego rozłożenia w czasie efektów publikacyjnych. Przykładowo, jeśli system motywacyjny wymaga minimalnej sumy punktów potrzebnych do otrzymania premii ${ }^{41}$, może się zdarzyć, że ukazanie się jednego dobrego artykułu w danym roku nie będzie wcale premiowane. Po drugie, system ten poszerza liczbę potencjalnych „dobrych autorów". W przypadku pracowników, którzy więcej uwagi przykładają do działalności dydaktycznej, opublikowanie dobrego artykułu będzie zawsze nagradzane. Podjęcie próby dobrej publikacji przez takiego pracownika nie wiąże się z ryzykiem, a korzyść jest pewna ${ }^{42}$. Nawet jeśli zdarzenia takie wystąpią incydentalne, wpłynie to korzystnie na przedstawiany przez uczelnie wykaz publikacji do oceny parametrycznej.

40 W nowej punktacji czasopisma mają otrzymać liczbę punktów od 20 do 200.

41 Jest to system, w którym przyjmuje się minimum punktów dla artykułu, jednocześnie wskazując ich minimalną sumę potrzebną do uzyskania premii.

42 Niepewność powstaje w systemie z minimalną sumą punktów. 
Motywowanie do wzmożonego wysiłku dydaktycznego nie jest proste, zwłaszcza w sytuacji możliwej substytucji aktywności dydaktycznej aktywnością badawczą. Duża liczba studentów potencjalnie wiąże się ze wzmożonym wysiłkiem dydaktycznym. Wprowadzenie w nowej ustawie referencyjnej liczby studentów na nauczyciela akademickiego teoretycznie niweluje element motywacji finansowej uczelni do maksymalizacji ich liczby, jednak oddziaływanie czynnika demograficznego będzie wpływać na przyjmowane przez podmioty strategie. Problemem, przed jakim staje uczelnia, jest pytanie, czy i jak motywować działalność dydaktyczną nauczycieli akademickich? Jak zabezpieczyć jej wysoką jakość? Powiązanie finansowania uczelni z liczbą studentów wskazywałoby na potrzebę wprowadzenia podobnego mechanizmu dla działalności dydaktycznej nauczyciela akademickiego. Wtedy można mówić o „zbieżności wektorów" dwóch systemów, na którą to potrzebę wskazywała prowadzona modelowa analiza. Liczba „obsługiwanych” studentów wpływa na wysiłek dydaktyczny. Odzwierciedlenie w systemie motywacyjnym ich wielkości przypadającej na pojedynczego pracownika wydaje się wartym rozważenia elementem.

Z przeprowadzonej modelowej analizy wynika, że powinno się zwracać uwagę na komplementarność wykonywanej pracy badawczej i dydaktycznej. Odpowiedni dobór kadry do siatki przedmiotów może mieć znaczenie dla jakości prowadzonej dydaktyki. Można dodatkowo rozważać jeszcze wprowadzenie syntetycznych mierników pracy dydaktycznej, jednak należy pamiętać o możliwości pojawienia się paradoksu efektywności.

Przy projektowaniu systemu motywacyjnego warto zastanowić się również nad strukturą otrzymywanego przez nauczyciela akademickiego wynagrodzenia. W analizowanym wcześniej modelu było ono liniowe oraz dzielone na części: stałą i zmienną. Im wyższa była część zmienna, tym większa motywacja. Mimo to należy pamiętać, że wysokie stałe wynagrodzenie podnosi koszt alternatywny. Samo w sobie staje się wtedy motywatorem do wytężonego wysiłku. Wydaje się, że polskie uczelnie, które będą mogły pozwolić sobie na wprowadzenie wysokich stałych podstaw wynagrodzeń, powinny przyciągać najlepsze kadry.

\section{Zakończenie}

Na podstawie przeprowadzonej analizy można sformułować następujące wnioski:

- Tworzony w części badawczej system motywacyjny powinien być oparty na punktach premiowych za każdą publikację powyżej danego limitu. 
- Powiązanie finansowania uczelni z liczbą studentów wskazywałoby na potrzebę wprowadzenia podobnego mechanizmu dla działalności dydaktycznej nauczyciela akademickiego.

- Wysiłek badawczy będzie pozytywnie oddziaływał na wysiłek dydaktyczny wyłącznie wtedy, gdy obie aktywności będą w stosunku do siebie komplementarne. Jakość dydaktyki może być podnoszona poprzez odpowiedni dobór kadry naukowej do siatki zajęć.

\section{Bibliografia}

\section{Akty prawne}

Ustawa z dnia 20 lipca 2018 r. Prawo o szkolnictwie wyższym i nauce (Dz.U. z 2018 r., poz. 1668).

\section{Opracowania}

Baker George P., Distortion and Risk in Optimal Incentive Contracts, The Journal of Human Resources, Autumn, 2002/37/4, s. 728-775.

Baker George P., Incentive Contracts and Performance Measurement, Journal of Political Economy 1992/100/3, s. 598-614.

Bolton Patrick, Dewatripont Mathias, Contract Theory, The MIT Press, London 2005.

Brickley James A., Zimmerman Jerold L., Changing incentives in a multitask environment: evidence from a top-tier business school, Journal of Corporate Finance 2001/7 (4), s. 367-396.

de Philippis Marta, Multitask agents and incentives: the case of teaching and research for university professors, Temi di Discussione (Working Papers) 2015/1042, s. 1-50.

Dewatripont Mathias, Jewitt Ian, Tirole Jean, Multitask agency problems. Focus and task clustering, European Economic Review 2000/44, Issues 4-6, s. 869-877.

Feltham Gerald, Xie Jim, Performance Measure Congruity and Diversity in Multi-Task Principal/Agent Relations, The Accounting Review 1994/69 (3), s. 429-453.

Fryer Jr. Roland G., Holden Richard T., Multitasking, dynamic complementarities, and incentives: A cautionary tale. Technical report, Cambridge, Massachusetts: Harvard University 2013.

Gibbons Robert, Incentives and Careers in Organizations, Journal of Economic Perspectives 1998/12 (4), s. 115-132.

GUS, Szkoły wyższe i ich finanse w 2017 r., Warszawa 2018.

Holmström Bengt, Milgrom Paul, Multitask Principal-Agent Analyses: Incentive Contracts, Asset Ownership, and Job Design, Journal of Law, Economics, \& Organization 1991/7 (1), s. 24-52.

Marsh Herbert W., Hattie John, The Relation between Research Productivity and Teaching Effectiveness: Complementary, Antagonistic, or Independent Constructs?, The Journal of Higher Education, Sep.-Oct., 2002/73/5, s. 603-641.

Meyer Marshall W., Gupta Vipin, The performance paradox, Research in Organizational Behavior 1994/16, s. 309-369.

Payne Abigail, Roberts Joanne, Government oversight of public universities: Are centralized performance schemes related to increased quantity or quality?, The Review of Economics and Statistics 2010/92 (1), s. 207-212. 
Piwowarski Radosław, Czy wskaźnik efektywności zatrudnieniowej ulega paradoksowi efektywności?, Acta Universitatis Lodziensis. Folia Oeconomica 2017/327 (1), s. 187-202.

Wilkin Jerzy, Instytucjonalne i kulturowe podstawy gospodarowania. Humanistyczna perspektywa ekonomii, Wydawnictwo Naukowe SCHOLAR, Warszawa 2016.

\section{Strony internetowe}

http://prawo.sejm.gov.pl/isap.nsf/DocDetails.xsp?id=WDU20180001668; stan na 22.06.2019 r. https://legislacja.rcl.gov.pl/projekt/12322309/katalog/12604666\#12604666; stan na 25.07.2019 r. https://nkn.gov.pl/wp-content/uploads/2017/09/uczelnie.pptx; stan na 18.07.2019 r.

\section{Załącznik 1}

Wyprowadzenie ekwiwalentnej funkcji użyteczności w warunkach pewności:

$$
\begin{aligned}
& \max _{r}, e_{t} E\left(U_{A}\left(w, e_{r}, e_{t}\right)\right)=E\left(-e^{-\eta\left[s+b\left(g_{r} e_{r}+g_{t} e_{t}+\varepsilon_{p}\right)-\frac{1}{2} e_{r}^{2}-\frac{1}{2} e_{t}^{2}-\delta e_{r} e_{t}\right]}\right)= \\
& \left(-e^{-\eta\left[s+b\left(g_{r} e_{r}+g_{t} e_{t}\right)-\frac{1}{2} e_{r}^{2}-\frac{1}{2} e_{t}^{2}-\delta e_{r} e_{t}\right]}\right) E\left(e^{-\eta b \varepsilon_{p}}\right)= \\
& -e^{-\eta\left[s+b\left(g_{r} e_{r}+g_{t} e_{t}\right)-\frac{1}{2} e_{r}^{2}-\frac{1}{2} e_{t}^{2}-\delta e_{r} e_{t}-\frac{\eta}{2} b^{2} \sigma_{p}^{2}\right]}
\end{aligned}
$$

\section{Załącznik 2}

Wyprowadzenie optymalnej wielkości „,b”.

$$
\begin{aligned}
& \max _{b}\left(\frac{f_{r} g_{r}-f_{r} \delta g_{t}}{1-\delta^{2}}\right)+\left(\frac{f_{r} g_{t}-f_{t} \delta g_{r}}{1-\delta^{2}}\right)-\left(\frac{b g_{r}-\delta b g_{t}}{1-\delta^{2}}\right)\left(\frac{g_{r}-\delta g_{t}}{1-\delta^{2}}\right) \\
& -\left(\frac{b g_{t}-\delta b g_{r}}{1-\delta^{2}}\right)\left(\frac{g_{t}-\delta g_{r}}{1-\delta^{2}}\right)-\delta\left(\frac{2 b g_{r} g_{t}-2 \delta b g_{t}{ }^{2}-2 b g_{r} g_{t}+2 \delta^{2} b g_{r} g_{t}}{1-\delta^{2}}\right) \\
& -\eta b \sigma_{p}^{2}=0 \\
& \quad \max \left(\frac{f_{r} g_{r}-f_{r} \delta g_{t}+f_{t} g_{t}-f_{t} \delta g_{r}}{1-\delta^{2}}\right)-\left(\frac{b g_{r}{ }^{2}-2 \delta b g_{t} g_{r}+\delta^{2} b g_{r} g_{t}}{1-\delta^{2}}\right) \\
& \quad b\left(\frac{b g_{t}{ }^{2}-2 \delta b g_{t} g_{r}+\delta^{2} b g_{r} g_{t}}{1-\delta^{2}}\right) \\
& -\delta\left(\frac{2 b g_{r} g_{t}-2 \delta b g_{t}{ }^{2}-2 \delta b g_{r}{ }^{2}+2 \delta^{2} b g_{r} g_{t}}{1-\delta^{2}}\right)-\eta b \sigma_{p}^{2}=0
\end{aligned}
$$




$$
\begin{aligned}
& \max _{b}\left(\frac{f_{r} g_{r}-f_{r} \delta g_{t}+f_{t} g_{t}-f_{t} \delta g_{r}-b g_{r}{ }^{2}+2 \delta b g_{t} g_{r}-\delta^{2} b g_{r} g_{t}-b g_{t}{ }^{2}+2 \delta b g_{t} g_{r}-\delta^{2} b g_{r} g_{t}}{1-\delta^{2}}\right) \\
& -\left(\frac{2 \delta b g_{r} g_{t}-2 \delta^{2} b g_{t}{ }^{2}-2 \delta^{2} b g_{r}{ }^{2}+2 \delta^{3} b g_{r} g_{t}}{1-\delta^{2}}\right)-\eta b \sigma_{p}^{2}=0 \\
& \max _{b}\left(\frac{f_{r} g_{r}-f_{r} \delta g_{t}+f_{t} g_{t}-f_{t} \delta g_{r}-b g_{r}{ }^{2}+2 \delta b g_{t} g_{r}-2 \delta^{2} b g_{r} g_{t}-b g_{t}{ }^{2}+2 \delta^{2} b g_{t}{ }^{2}+2 \delta^{2} b g_{r}{ }^{2}-2 \delta^{3} b g_{r} g_{t}}{1-\delta^{2}}\right) \\
& -\frac{\left(\eta b \sigma_{p}^{2}\right)\left(1-\delta^{2}\right)}{1-\delta^{2}}=0 \\
& \max _{b}\left(\frac{f_{r} g_{r}-f_{r} \delta g_{t}+f_{t} g_{t}-f_{t} \delta g_{r}}{1-\delta^{2}}\right) \\
& +b\left(\frac{-g_{r}{ }^{2}+2 \delta g_{t} g_{r}-2 \delta^{2} g_{r} g_{t}-g_{t}{ }^{2}+2 \delta^{2} g_{t}^{2}+2 \delta^{2} g_{r}{ }^{2}-2 \delta^{3} g_{r} g_{t}-\left(\eta \sigma_{p}^{2}\right)\left(1-\delta^{2}\right)}{1-\delta^{2}}\right) \\
& =0 \\
& \begin{array}{l}
\max _{b}\left(\frac{f_{r} g_{r}-f_{t} g_{t}-\delta\left(f_{t} g_{r}-f_{r} g_{t}\right.}{1-\delta^{2}}\right) \\
+b\left(\frac{2 \delta^{2}\left(g_{t}{ }^{2}+g_{r}{ }^{2}\right)+2 \delta g_{t} g_{r}\left(1-\delta-\delta^{2}\right)-g_{r}{ }^{2}-g_{t}{ }^{2}-\left(\eta \sigma_{p}^{2}\right)\left(1-\delta^{2}\right)}{1-\delta^{2}}\right) \\
=0
\end{array} \\
& \max _{b}\left(\frac{f_{r} g_{r}-f_{t} g_{t}-\delta\left(f_{t} g_{r}-f_{r} g_{t}\right.}{1-\delta^{2}}\right) \\
& -b\left(\frac{g_{r}{ }^{2}+g_{t}{ }^{2}-2 \delta^{2}\left(g_{t}{ }^{2}+g_{r}{ }^{2}\right)-2 \delta g_{t} \mathrm{~g}_{r}\left(1-\delta-\delta^{2}\right)+\left(\eta \sigma_{p}^{2}\right)\left(1-\delta^{2}\right)}{1-\delta^{2}}\right) \\
& =0
\end{aligned}
$$


Radosław PIWOWARSKI

\title{
INCENTIVES FOR ACADEMIC TEACHERS IN POLAND IN THE CONTEXT OF THE MULTITASKING AGENCY MODEL
}

\begin{abstract}
Background: Shaping motivations in the principal-agent relationship is the basis for the effective functioning of both market entities and organizations. The multitasking problem at universities is associated with hidden actions (moral hazard). The inability to constantly monitor the work of an academic teacher and the difficulty in measuring his/her effectiveness are conducive to the emergence of these phenomena. The problem can be solved by a properly designed contract.

Research purpose: The aim of the article is to analyze solutions relating to the system of financing higher education contained in the Act of 20 July 2018 - the Law on Higher Education and Science - in the context of the Multitasking Agency Model. On this basis, proposals for incentive solutions that increase the effectiveness of the Polish academic teacher's work are presented.

Methods: The article analyzes the multitasking agency model, which is then complemented with empirical data and a description of juridical solutions.

Conclusions: Considering the teachers' research activities, the incentive system should be based on bonus points for each publication above a given point floor, while linking university funding with the number of students would indicate the need to introduce a similar mechanism for didactic activities.
\end{abstract}

Keywords: agency theory, principal-agent model, incentive system, universities in Poland. 